\title{
Detection a New Antiseptic Resistant Variant of qac Gene in Some Multi Drug Resistant Staphylococcus aureus Isolated from Different Clinical Sources
}

\author{
Noor Saber
}

Nuha Joseph Kandala*

Hiba Abdulameer Mohammed

\author{
Received 1/6/2018, Accepted 20/2/2019, Published 1/9/2019
}

This work is licensed under a Creative Commons Attribution 4.0 International License.

\begin{abstract}
:
The increasing use of antiseptic compounds creates selective pressure cause emergence of antiseptic resistance among Staphylococcus aureus .Resistance mechanism of antiseptic is driven mainly by multi drug resistant (MDR) efflux protein.Sixty five isolates of S.aureuswere collected from different clinical sources and subjected to 11 antibiotics most of them are recognized by efflux systems as extruded substrates. Range of efflux activity was estimated using cartwheel method. Simultaneous discrimination of antiseptic coding genes (qacA/B, smr and norA)as well as nuc and mecA genes among multidrug resistantS.aureus(MRSA) isolates was preformed using multiplex PCR assay, 61 isolatesamong 65 were positive tonисаnd mecA genes, 58 of them were positive to nor $\mathrm{A}, 14$ of them were positive to qac $\mathrm{A} / \mathrm{B}$ and only two were positive to $s m r$. All isolates detected with qac $\mathrm{A} / \mathrm{B}$ characterized by fluoroquinolones resistant and most of them show strong efflux activity at cartwheel assay, all of the 14 isolates positive qac $\mathrm{A} / \mathrm{B}$ were sequenced to differentiate between variants depending on position 323 (aspartic in QacA, alanine in QacB), 3 of them harbored asparagines amino acid at position 323 and considered to be a new variants that reported for the first time.
\end{abstract}

Keywords: Efflux pump , Multiplex PCR , Staphylococcus aureus, Transmembrane domain,

\section{Introduction:}

Antiseptic efflux pumps possessed by S.aureus belong mainly to major facilitator superfamily (MFS) and small multi drug resistance family (SMR) and harbored by plasmid- or chromosomally based located $(1,2)$. Staphylococcal efflux determinants can be specialized to export one type of drug such as TetK efflux pump or transport vast array of unrelated compound (antiseptics, dyes, and antibiotics) included mainly chromosomal NorA efflux protein (3). Plasmid encoded proteins Quaternary Ammonium Compunds (QacA) and (QacB)(4) and Small Multidrug resistance family(smr) (5) .Effluxes machinery belong to MFS and SMR family that uses secondary transporting system depend on ion moving $(\mathrm{H}+, \mathrm{K}+)$ in electrochemical concentration gradients called proton motive force as energy source involved in transporting substrate from inside bacteria cell to surrounding environment to reduc intracellular concentration of toxic compound $(1,6,7)$.

Department of Biology, College of Science, University of Baghdad, Baghdad, Iraq.

*Corresponding author: nuhakasto@yahoo.com
The multi-drug resistance (MDR) pattern efflux pump that belongs to efflux family when consists of different number of monomers, 4 segments (Smr), 12 segments flouroquinoline efflux transporter protein (norA) and 14 segment (QacA, QacB) called transmembrane helices(8,9).Efflux pump is classified as one of the mechanisms contributes to MDR phenotype in methicillin resistant S.aureus since resistance of antibioticsbiocides is interface (10).Chromosomal active efflux mediated by NorA extrude multiple targets included quaternary ammonium compounds (tetraphenylphosphonium bromide, cetrimide, benzelkonium chloride), fluoroquinolones antibiotics (Norfloxacin, enoxacin, ofloxacin, ciprofloxacin) and intercalating dyes(11,12) and (13).Although the chromosomal NorA transporter possesses higher recognizing target ability than plasmid based effluxes, QacA/B efflux pump with 14 a-helix transmembrane segments displayed exceptionally wide range of substrate specificity, qacA shared great homology; genetic resemblance with qacB which distorted in 6 positionS only Single nucleotide polymorphisms (SNPs) at codon 323 provide non-conserved change in amino acid (Aspartic in QacA protein to Alanine in QacB protein) which clarifies their specificity differences 
$(6,14)$,now $q a c \mathrm{~A}$ and $q a c \mathrm{~B}$ are called $q a c \mathrm{~A} / \mathrm{B}$ genes since they share high homology (5),some early observations hypothesized that plasmid basedantiseptic resistance can be found as part of S.aureus chromosome since it is harbored by transposon (6).Biocides resistance in S.aureus also contributed by smr; historically known (qacC, ebrand $q a c \mathrm{D}$ ) which confers resistance to some quaternary ammonium compound and ethidium bromide $(15,6)$. As far as we know, the current study is the first report that was investigated the occurrence of antiseptic resistance determinates among Methicilin Resistant Staphylococcus aureus (MRSA) isolates collected from different clinical cases.

\section{Materials and Method:}

\section{Collection and Characterization of}

\section{S.aureusIsolates}

The 65 clinical samples were collected from different sites of patients attending AL WassetyHospital, Al-Yarmouk Hospital, kindy Hospital and Al-Karama hospital in Baghdad, these samples were distributed as follows: food ulcers( 44 isolate), urinary tract infection( 12 isolate), nasal(5 isolates), oral (2 isolates) and wound( 2 isolates). These samples were collected from January 2017 to March 2017. Sixty one isolate were identified as S.aureus, these isolates were characterized according to Bergey's manual of Systematic Bacteriology (16).

\section{Antibiotics Susceptibility Test}

Resistance pattern of collected isolates were tested against 11 antibiotics and most of them were resisted by efflux pump including cefoxitin(FOX-30 $\mu \mathrm{g}$ ), meropenem (MEM-10 $\mu \mathrm{g}$ ), ceftriaxone (CRO-

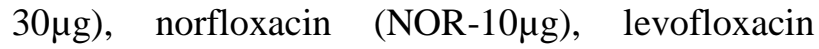
(LEV-5 $\mu \mathrm{g}$ ), ciprofloxacin (CIP-5 $\mu \mathrm{g})$, erythromycin $(\mathrm{E}-15 \mu \mathrm{g})$, tetracycline $(\mathrm{T}-10 \mu \mathrm{g})$, trimethoprim (TM-

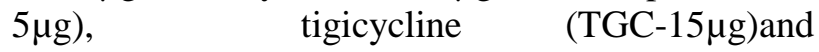
Vancomycin(VA- 30 )using Kirby-Bauer method.

\section{Cartwheel Test}

Conventional Ethidium bromide-agar evaluation procedure(17)was used to evaluate the expression level of efflux transporter protein within sixty one isolates; to achieve this purpose multiple concentration of trypton soy agar containing ethidium bromide plate were prepared $(0,0.25,0.5$, 1,2 and 4) $\mathrm{mg} / \mathrm{l}$.

\section{Minimum Inhibitory Concentration(MIC)}

Stock solutions of benzylkonium chloride $(50 \%)$, chlorohexidine glucanoate $(4 \%)$, cetrimide and chloroxylenol prepared according to (18).

\section{DNA Extraction and Multiplex PCR}

All bacterial isolates were activated on 10 $\mathrm{ml}$ of LauriaBertani (LB) broth containing $0.2 \mathrm{mg} / \mathrm{ml}$ of ampicillin, and incubated at $37^{\circ} \mathrm{C}$ for $18 \mathrm{hr}$,Genomic DNA was extracted using salting out method (19). Plasmid DNA was extracted efficiently using PureYield ${ }^{\mathrm{TM}}$ Plasmid Miniprep System (Promega/USA). Simultaneous discrimination using multiplex PCR was accomplished to provide rapid efflux pumps detection and initial diagnosis of methicillin resistant S.aureus in one PCR run.The ideal reaction annealing temperature of (nuc, norA and qacA/B-1) primers mixture was $54^{\circ} \mathrm{C}$ while annealing temperature for mec A was $60{ }^{\circ} \mathrm{C}$ for 45 seconds in the presence of $50 \mathrm{ng}$ genomic DNA as template in one PCR program using two temperatures $(54,60)^{\circ} \mathrm{C}$ Table1, Second Multiplex PCR run was achieved using plasmid DNA as template to detect efflux pumps genes (qacA/B and $s m r$ ) harbored by plasmid only, two primers were used to target two different regionsinqac $\mathrm{A} / \mathrm{B}$ and one primer was used to detect $s m r$ gene, Optimum amplification parameters for primers $q a c \mathrm{~A} / \mathrm{B}-1, q a c \mathrm{~A} / \mathrm{B}-2$ and $s m r$ were $57^{\circ} \mathrm{C}$ for 45 seconds using only plasmid DNA, Table 2, primers sequences are listed in Table 3.

Table 1. The program of $q a c \mathrm{~A} / \mathrm{B}$, nor $\mathrm{A}$, mec $\mathrm{A}$ and nuc primers in PCR analysis with two different temperature.

\begin{tabular}{cccc}
\hline Steps & Temperature ${ }^{\circ} \mathbf{C}$ & Time & No. of cycles \\
\hline $\begin{array}{c}\text { Initial } \\
\text { denaturation }\end{array}$ & 94 & $5 \mathrm{~min}$ & 1 cycle \\
Denaturation & 94 & $45 \mathrm{sec}$ & \\
Annealing & $\mathbf{5 4}$ & & \\
Annealing & $\mathbf{6 0}$ & $45 \mathrm{sec}$ & 35 cycles \\
Extension & 72 & $45 \mathrm{sec}$ & \\
Denaturation & 94 & $45 \mathrm{sec}$ & \\
Final extension & 72 & $7 \mathrm{~min}$ & 1 cycle \\
\hline
\end{tabular}

Table 2. PCR program for qacA/B-1, qacA/B-2 and smr primers.

\begin{tabular}{lllc}
\hline Steps & Temperature ${ }^{\circ} \mathbf{C}$ & Time & NO. of cycles \\
\hline Initial & 94 & $5 \mathrm{~min}$ & 1 cycle \\
denaturation & & & \\
Denaturation & 94 & $1 \mathrm{~min}$ & \\
Annealing & 57 & $45 \mathrm{sec}$ & 35 cycles \\
Extension & 72 & $1 \mathrm{~min}$ & \\
Final extension & 72 & $5 \mathrm{~min}$ & 1 cycle \\
\hline
\end{tabular}


Table3. Primer sequence and amplicon size

\begin{tabular}{cccc}
\hline Primer & Sequence (5'......3') & Amplicon size (bp) & References \\
\hline nuc-F & GCGATTGATGGTGATACGGTT & 276 & $(20)$ \\
nuc-R & AGCCAAGCCTTGACGAACTAAAGC & & \\
mecA-F & GTGAAGATATACCAAGTGATT & 147 & $(21)$ \\
mecA-R & ATGCGCTATAGATTGAAAGGAT & & \\
qacA/B-1R & GCTGCATTTATGACAATGTTTG & 630 & $(22)$ \\
qacA/B-1F & AATCCCACCTACTAAAGCAG & 361 & $(23)$ \\
qacA/B-2 F & GCAGAAAGTGCAGAGTTCG & & \\
qacA/B-2 R & CCAGTCCAATCATGCCTG & 157 & \\
smr-F & AAACAATGCAACACCTACCACT & 314 & \\
smr-R & AACGAAACTACGCCGACTATG & & \\
norA-F & GGCGGTATATTTGGGGCACT & & \\
norA-R & ACGCACCTGCGATTAAAGGA & & \\
\hline
\end{tabular}

\section{Sequencing of PCR Product}

The amplified products of this study contain 3 diagnostic Single Nucleotide Polymorphysim (SNP) positions in order to differentiate between $q a c \mathrm{~A}$ and $q a c \mathrm{~B}$ on that basis; the FASTA sequence of both genes were downloaded from sequence database in gene bank then compared with sequence of amplified product by basic local alignment search tool (BLAST) which is available at National center of biological information (NCBI) website, the amplified segment by qacA/B-1 primer covering region between nucleotide number 844 and 1454, single nucleotide polymorphism (SNP) genotype assay designed to differentiate $q a c \mathrm{~A}$ from $q a c \mathrm{~B}$ according to SNPs at position: codon 320 (GCA/GAA), codon 323 (GAT/GCT) and codon 380 (ATG/ACG).

\section{Results and Discussion \\ Biotyping Antibiotic/Antiseptics Susceptibility}

In this study, A total of 65 local isolates were characterized depending on cultural and microscopic characteristics. Morphologically, 61 isolates grow and shows smooth, translucent, creamy, yellow pigmented colonies onmannitol salt agar and fermented mannitol. Microscopically examination showed that the bacterial cells positive for gram stain reaction and appeared as grape like clusters, non sporeformingand non motile.Several biochemical tests were performed, and the results demonstrated that 61 isolates gave positive results for catalase, coagulase, and negative for oxidase test. All isolates subjected to 11 antimicrobial agents.The sensitivity result showed that oxacillin resistant phenotype present in $(70.49 \%)$ of isolates represented by resistance to cefoxitin, ceftriaxone, meropenem (24) resistant percentage of S.aureus isolates to norfloxacin, ciprofloxacin, and levofloxacin was $59.06 \%$. While resistance percentage to tetracycline, erythromycin, trimethoprim, and tigecyline was (63.93, 70.49, 36.06 and 0)\% respectively. Cartwheel method was used to estimate the efflux activity within MDR S.aureus, All of the 61 isolates were cultured on trypton soy agar containing different concentrations of ethidium bromide (EtBr), absence of florescence from cultured bacterial mass under UV light considered as a clue for positive efflux activity, 38 isolate possessed the phenotypic characters of efflux protein since the resistance of ethidium bromide related to the resistance of antiseptics and designated as main substrate for the study of membrane proteins (25),from these 13 isolate were positive at higher concentration of 2 and $4 \mathrm{mgll}$ of $\mathrm{EtBr}$, while 25 isolates were negative detected with florescence under UV light in the presence of low concentration of $\operatorname{EtBr}(0.25,0.5) \mathrm{mg} / \mathrm{l}$ (Figure -1,2 and 3). In order to confirm cartwheel test result, 8 isolates that showed high efflux activity at 2 and 4 $\mathrm{mg}$ of $\mathrm{EtBr}$ were tested against cetrimide, chloroxylenol, chlorohexidineglucanoate and benzylkonium chloride, the MIC of these isolates was $>625 \mu \mathrm{g} / \mathrm{ml}$ for cetrimide and chloroxylenol, for benzylkonium chloride was $>500 \mu \mathrm{g} / \mathrm{ml}$. 


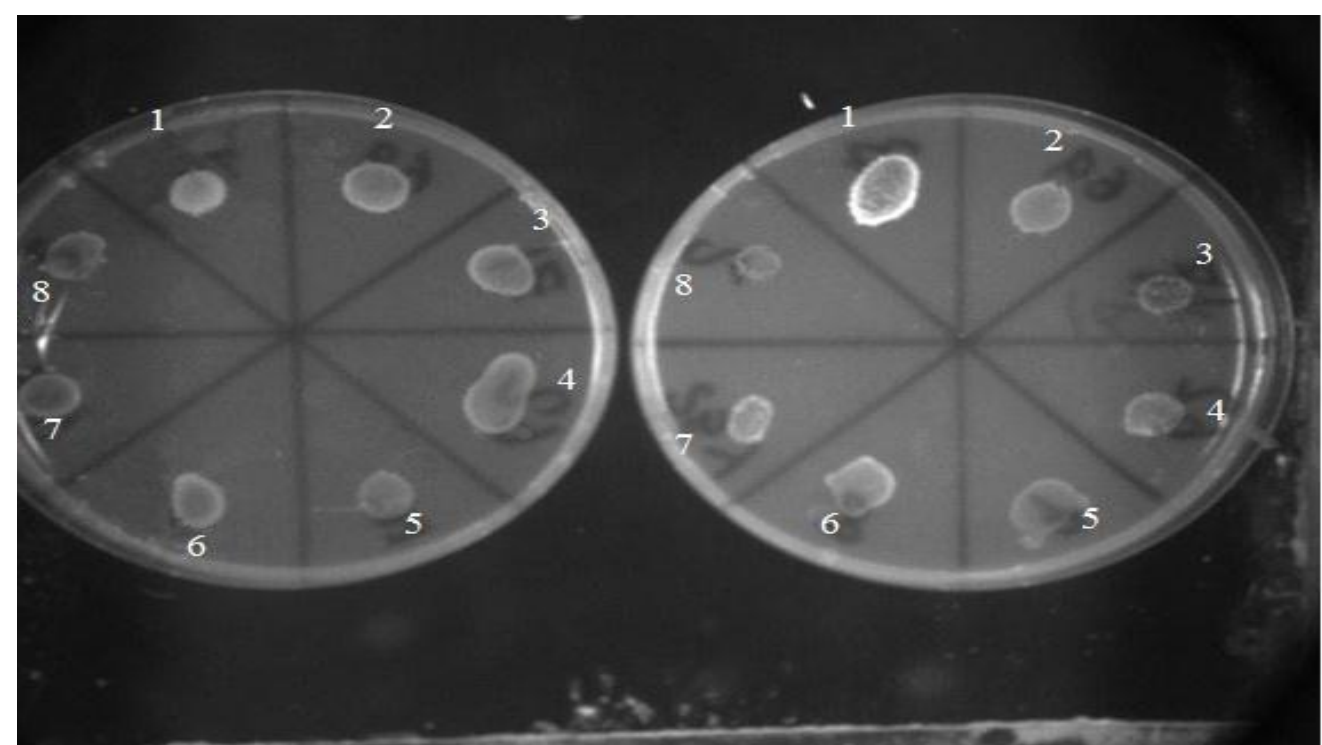

Figure 1. The fluorescence associated with clinical isolates of S.aureus on0.25mg/l of EtBr-TSA plates visualized under UV light with gel documentation. All isolates recorded as positive at $0.25 \mathrm{mg} / \mathrm{l}$ of ethidium bromide except isolates on section 1.

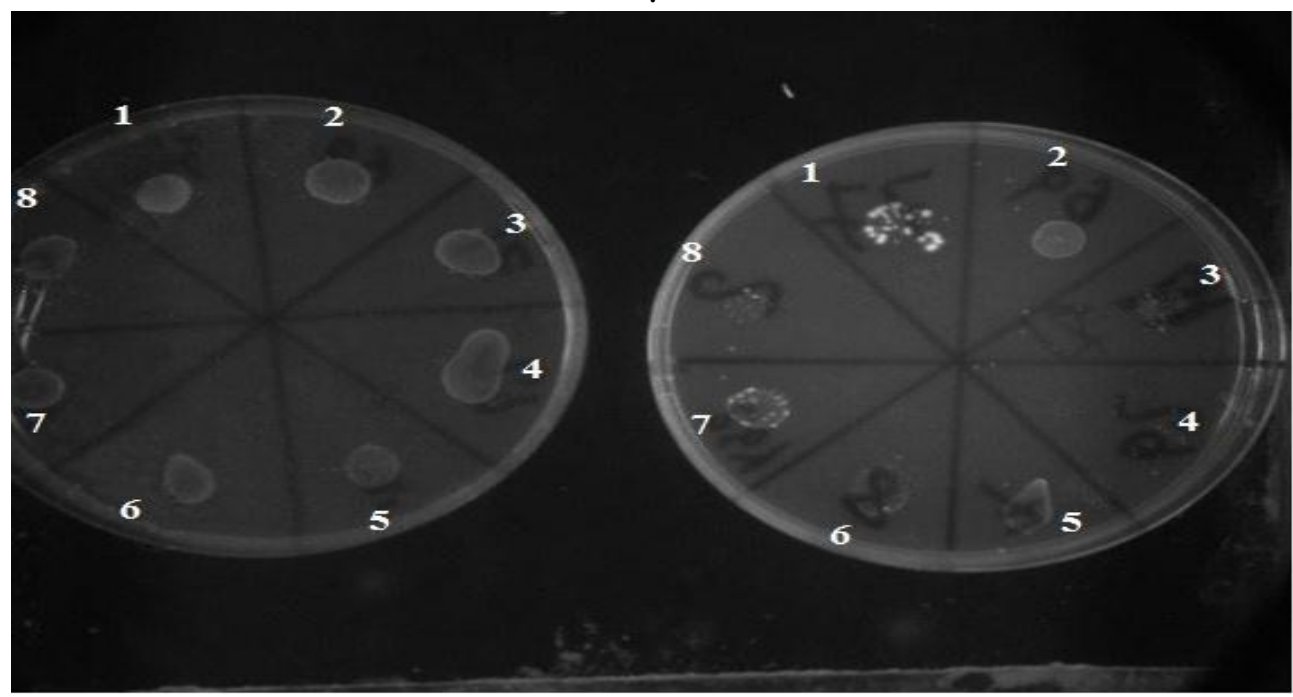

Figure 2. Positive and negative efflux pump related to S.aureus isolates at $0.5 \mathrm{mgV}$ ofEtBr-TSA plates visualized under UV light with gel documentation.

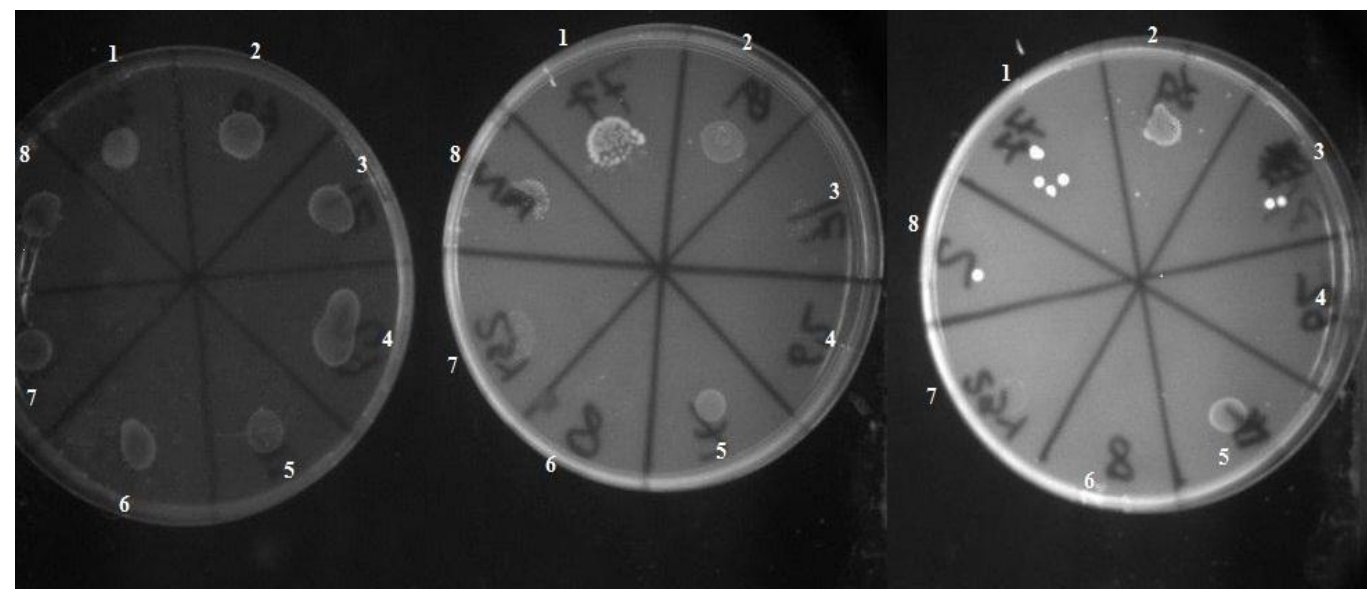

Control plate

$2 \mathrm{mg} / \mathrm{l}$

$4 \mathrm{mg} / 1$

Figure 3. Efflux pumps over expression displayed by S.aureus isolates represented in section $(2,3,5$, and 7), this isolates extruded chromophore efficiently. 
Detection of Antiseptic Coding Genes in MRSA Isolates

Qacs protein (A/B,Smr) encoded by determinants harbored on large plasmids or small plasmids in case of $s m r$ gene, or in some cases such genes encoded by chromosomal DNA as result of transposon (26). Two multiplex PCR programs were used to detect the $q a c \mathrm{~A} / \mathrm{B}$ gene within genomic DNA and for plasmid DNA, the first assay used genomic DNA as template, all isolates were positive $(100 \%)$ for nucand mecA with gene bands molecular weight $267 \mathrm{bp}$ and $147 \mathrm{bp}$ respectively. Fifty six isolates $(91.80 \%)$ documented as positive for norA (314bp) and only fourteen isolates of S.aureuswere positive to qacA/B (22.95\%) with a band has molecular weight of $630 \mathrm{bp}$ as shown in Figure 4.

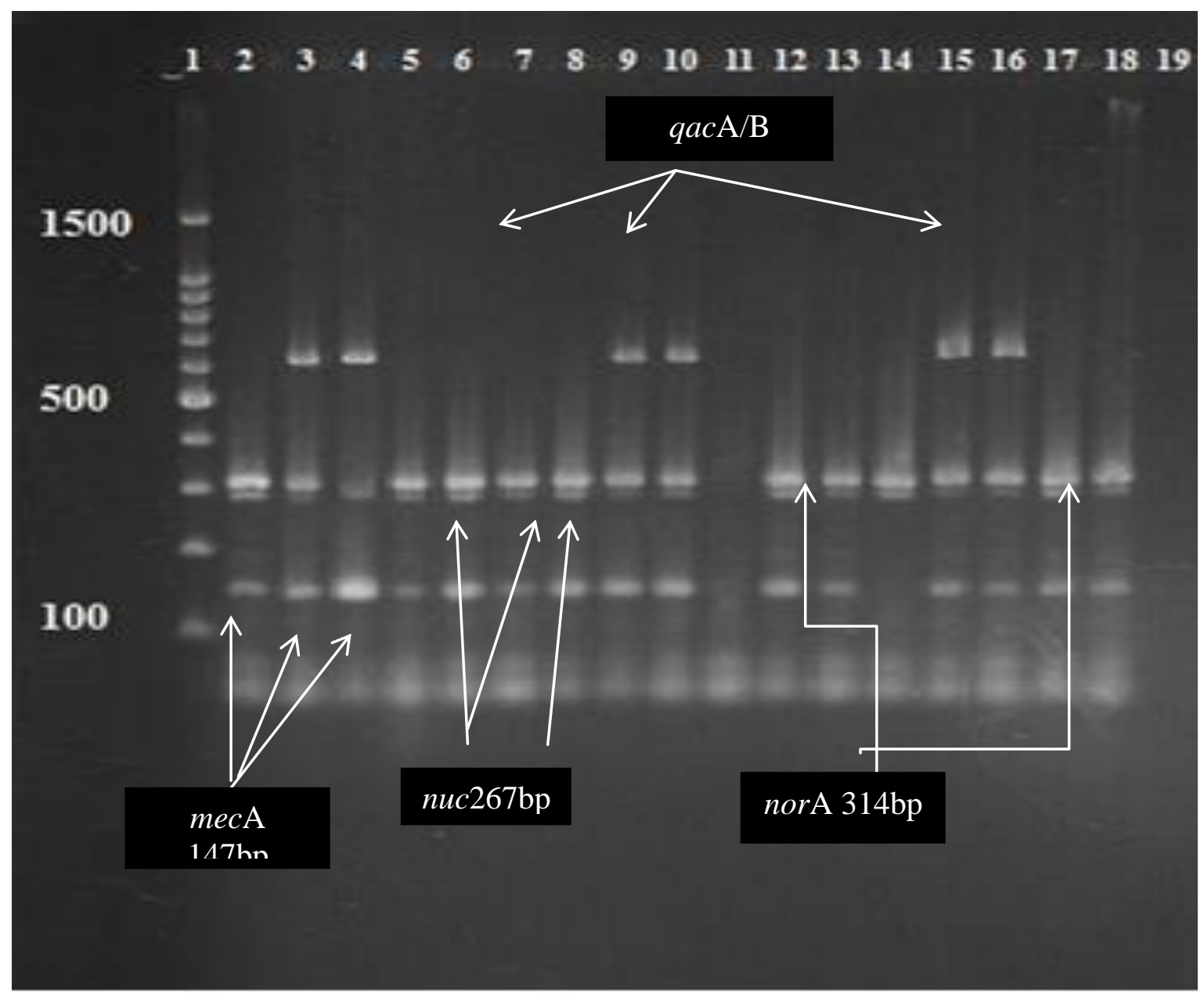

Figure 4. Agarosre gel electrophoresis of multiplex PCR amplification for efflux pumps (norA and $q a c \mathrm{~A} / \mathrm{B}$ ) genes in MRSA isolates diagnosed by (nuc and mec A) and visualized by UV light after staining by ethidium bromide. Line 1: represent ladder (100-1500 bp), line 11: reactors without template, line 19: negative control, the qac $\mathrm{A} / \mathrm{B}$ 630bp line $(3,4,9,10,15,12)$ and lines $(3,4,5,6,7,8,9,11,12,13)$ norA 310bp, mec $A(147 \mathrm{bp})$ and nuc (267bp) in all lines except line 11 and 19 .

Among 36 isolates positive to phenotypic detection of efflux pump only two were negative to norA,although the role of norA in antiseptic resistance, this study found out that norA gene present even among isolates without efflux activity, such condition possibly resulted fromnegative regulation of norA by the global regulator $m g r A$; member of marR group of regulator (2). This highly incidence level of norA mainly because that norA likes other chromosomally encoded efflux determinants; are highly conserved and should be predominant in all S.aureus isolates (11).As a result, this study predicted prevalence of antiseptic and antibiotic resistant determinant (norA) in Iraqi clinical MDR S.aureus isolates, The emergence of qac $\mathrm{A} / \mathrm{B}$ gene was limited to only fourteen MRSA isolates among the selected samples $(22.95 \%)$ with unique band 630bp; Twelve of them showed efflux activity in phenotypic examination and most of them were also positive to norA. The screening of the second run targeted two region of $q a c \mathrm{~A} / \mathrm{B}$ by two primers (630bp and $361 \mathrm{bp}$ ) and $s m r$ gene (157bp) among the plasmids of all selected samples as represented in Fig. 5. 


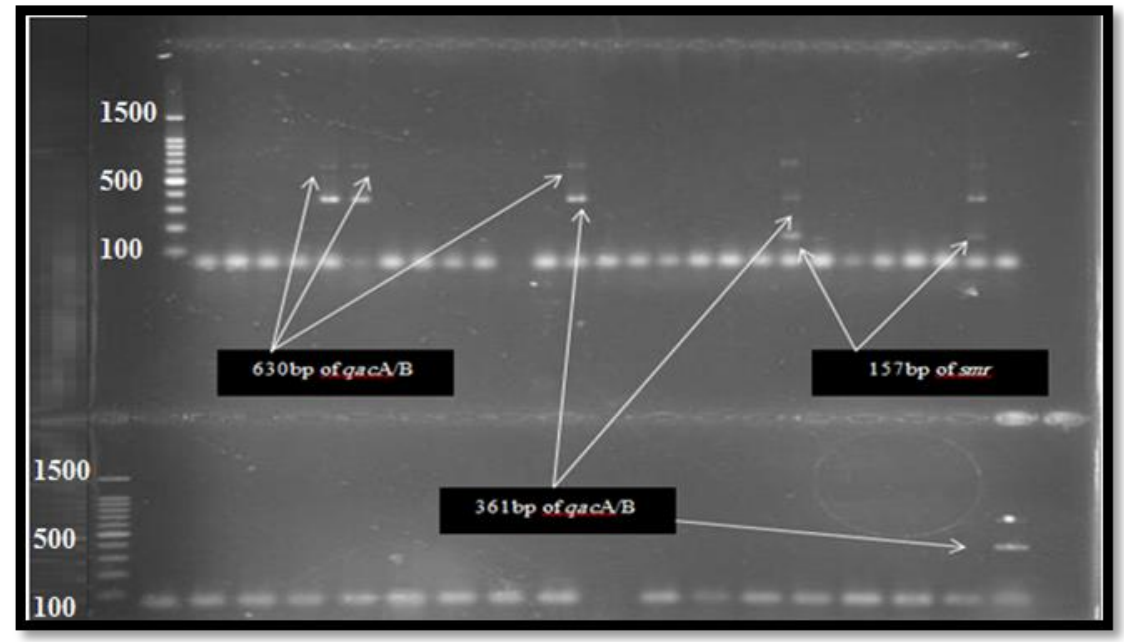

Figure 5. Detection of $q a c \mathrm{~A} / \mathrm{B}$ and $s m r$ among plasmid DNA by triplex PCR visualized by U.V light after electrophoresis and staining for $20 \mathrm{~m}$ in EtBr solution (2\% agarose ).

The first run for multiplex PCR for screening of $q a c \mathrm{~A} / \mathrm{B}$ gene revealed fourteen positive isolates, however the second run detected only nine positive isolates. This study argued that qac A / $\mathrm{B}$ in these five isolates located on the chromosome. Such condition was reported by (27)in which qacA/B could be found as a part of the chromosome of clinical S.aureus isolates. The smr gene detected in two isolates only in the first and seconed run of multiplex PCR, and these isolates were also positive for mecA, nor A and qacA/B. This is the first study in Iraq that investigated prevalence level of antiseptic/disinfectant resistant determinants among local S.aureus isolates. Among the 14 isolates that detected with qacA/B gene, 12 isolates of them were previously documented as positive to efflux pumps with cartwheel test; and only two isolates were negative but possesses MDR pattern, (Table -2).

Table 2. Efflux/antibiotic resistance pattern among S.aureus isolates positive to qac $\mathrm{A} / \mathrm{B}$.

\begin{tabular}{|c|c|c|c|c|c|}
\hline ID & $\begin{array}{l}\text { Positive EA at cartwheel test } \\
(\mathrm{mg} / \mathrm{l})\end{array}$ & $\mathrm{CNL}$ & $\mathrm{TM}$ & $\mathrm{T}$ & $\mathrm{E}$ \\
\hline 1 & $\mathrm{P}(4)$ & $\mathrm{R}$ & $\mathrm{R}$ & $\mathrm{R}$ & $\mathrm{R}$ \\
\hline 2 & $\mathrm{P}(1)$ & $\mathrm{R}$ & $\mathrm{R}$ & $\mathrm{R}$ & $\mathrm{R}$ \\
\hline 3 & $\mathrm{P}(4)$ & $\mathrm{R}$ & $\mathrm{R}$ & $\mathrm{R}$ & $\mathrm{R}$ \\
\hline 4 & $\mathrm{~N}$ & $\mathrm{R}$ & $\mathrm{R}$ & $\mathrm{S}$ & $\mathrm{S}$ \\
\hline 5 & $\mathrm{P}(4)$ & $\mathrm{R}$ & $\mathrm{R}$ & $\mathrm{R}$ & $\mathrm{R}$ \\
\hline 6 & $\mathrm{P}(2)$ & $\mathrm{R}$ & $\mathrm{R}$ & $\mathrm{R}$ & $\mathrm{R}$ \\
\hline 7 & $\mathrm{P}(2)$ & $\mathrm{R}$ & $\mathrm{R}$ & $\mathrm{R}$ & $\mathrm{R}$ \\
\hline 8 & $\mathrm{P}(1)$ & $\mathrm{R}$ & $\mathrm{R}$ & $\mathrm{R}$ & $\mathrm{R}$ \\
\hline 9 & $\mathrm{P}(2)$ & $\mathrm{R}$ & $\mathrm{R}$ & $\mathrm{R}$ & $\mathrm{R}$ \\
\hline 10 & $\mathrm{P}(2)$ & $\mathrm{R}$ & $\mathrm{S}$ & $\mathrm{S}$ & $\mathrm{S}$ \\
\hline 11 & $\mathrm{P}(0.5)$ & $\mathrm{R}$ & $\mathrm{S}$ & $\mathrm{S}$ & $\mathrm{S}$ \\
\hline 12 & $\mathrm{P}(4)$ & $\mathrm{R}$ & $\mathrm{R}$ & $\mathrm{R}$ & $\mathrm{R}$ \\
\hline 13 & $\mathrm{P}(4)$ & $\mathrm{R}$ & $\mathrm{R}$ & $\mathrm{R}$ & $\mathrm{R}$ \\
\hline 14 & $\mathrm{~N}$ & $\mathrm{R}$ & $\mathrm{R}$ & $\mathrm{R}$ & $\mathrm{R}$ \\
\hline
\end{tabular}

EA: efflux activity, P: positive, N: Negative, CNL: Ciprofloxacin, Norfloxacin,

Levofloxacin, TM: trimethoprim, T: tetracycline, E: erythromycin.

All isolates with antiseptic resistant qac $\mathrm{A} / \mathrm{B}$ gene characterized by fluroquinulones resistance, $m e c \mathrm{~A}$ positive and resistance to cefoxitine, the incidence of $q a c \mathrm{~A} / \mathrm{B}$ and $s m r$ in MRSA isolates only is comprehensible since multi-resistance is handled by plasmids as revealed by (28).Seven isolates were identical $100 \%$ to the reference sequences of qacA gene five of them were amplified from plasmid and two amplified from chromosome, other 6 isolates were identical $99 \%$ to $q a c \mathrm{~A}$ reference sequences, only one isolate has $85 \%$ identity to reference sequences of qacA.Multiple SNPs at different lociofqacA were recorded at NCBI ( Table-3). The change should be $(A>G)$ to converet ATG codon coding for asp to AAT codon coding for asn at position 323which is responsible for specific differences between QacA and QacB a new SNP in qacA gene at this position $(A>G)$ was detected leading to amino acid change (Asp to Asn). As a result, this study detected a new variant form of antiseptic resistant qac gene (called qac $\mathrm{A}^{\prime}$ by this study) in addition to qac $\mathrm{A}$ and qacBwhich are 
carried by three isolates; two isolates were collected obtained from patient with UTI. from foot ulcer of diabetic patients and one was

Table 3: Detection of new SNPs among positive qac AS.aureus isolates.

\begin{tabular}{|c|c|c|c|c|c|c|c|}
\hline $\begin{array}{l}\text { Isolate } \\
\text { number }\end{array}$ & $\begin{array}{c}\text { Collection } \\
\text { source }\end{array}$ & $\begin{array}{c}\text { Origin of } \\
\text { amplification }\end{array}$ & unrecorded SNP detected & Amimo acid change & $\begin{array}{l}\text { Position } \\
\text { number }\end{array}$ & $\begin{array}{l}\text { Identified (\%) } \\
\text { and Gaps }\end{array}$ & $\begin{array}{c}\text { NCBILocus } \\
\text { Code }\end{array}$ \\
\hline 1 & Foot ulcer & Plasmid & - & - & $\cdot$ & (100) and 0 gaps & \\
\hline 2 & Foot ulcer & Plasmid & $\cdot$ & $\cdot$ & $\cdot$ & (100) and 0 gaps & \\
\hline 3 & Foot ulcer & Plasmid & - & - & - & (100) and 0 gaps & \\
\hline 4 & Foot ulcer & Chromosome & $\cdot$ & $\cdot$ & - & (100) and 0 gaps & \\
\hline 5 & Foot ulcer & Plasmid & - & - & - & (100) and 0 gaps & \\
\hline 6 & Foot ulcer & Plasmid & TTT $>$ ATT & $\mathrm{F}>\mathrm{I}$ & 352 & (99) and 0 gaps & \\
\hline \multirow[t]{2}{*}{7} & Foot ulcer & Plasmid & $T T T>A T T$ & $\mathrm{~F}>\mathrm{I}$ & 352 & (99) and 0 gaps & LC335718 \\
\hline & & & AATSGAT & N>D & 323 & & \\
\hline \multirow[t]{2}{*}{8} & Foot ulcer & Chromosome & $\mathrm{AAT}>\mathrm{GAT}$ & $\mathrm{N}>\mathrm{D}$ & 323 & (99) and 0 gaps & LC335719 \\
\hline & & & $\mathrm{AAG}>\mathrm{GAG}$ & $\mathrm{K}>\mathrm{E}$ & 408 & & \\
\hline 9 & Foot ulcer & Plasmid & $\cdot$ & - & - & (100) and 0 gaps & \\
\hline 10 & Foot ulcer & Chromosome & $\cdot$ & $\cdot$ & $\cdot$ & (100) and 0 gaps & \\
\hline 11 & Foot ulcer & Chromosome & TTT $>A T T$ & $\mathrm{~F}>\mathrm{I}$ & 352 & (99) and 0 gaps & LC335717 \\
\hline \multirow[t]{2}{*}{12} & UTI & Plasmid & TGT>TAT & $\leftrightarrow \mathrm{Y}$ & 358 & (99) and 0 gaps & LC335720 \\
\hline & & & $\mathrm{GTT}>\mathrm{GCT}$ & $\mathrm{V}>\mathrm{A}$ & 378 & & \\
\hline 13 & UTI & Plasmid & $\begin{array}{l}\mathrm{AAT}>\mathrm{GAT} \\
\mathrm{AAA}>\mathrm{GAA}, \\
\mathrm{AAA}>\mathrm{GAA}\end{array}$ & $\frac{N>D,}{K>E, K>E}$ & $\frac{323,}{393,407}$ & (99) and 0 gaps & LC335721 \\
\hline 14 & UTI & Chromosome & $\cdot$ & $\cdot$ & - & (85) and 4 gaps & \\
\hline
\end{tabular}

\section{Conclusion:}

The resistance of MRSA isolates to disinfectant and antiseptic compounds mediated mainly by plasmids $q a c \mathrm{~A} / \mathrm{B}$ and $s m r$ determinants and by chromosomal norA gene, The occurrence of such determinants occupied by MDR resistant pattern in MRSA isolates toward multiple targets leading to cross-resistance between antibioticantiseptics in local isolates.Consenquantly these isolates must be detected by efflux activities and their genotypic coding factors. In this study, a new qacdeterminant variant spreading among MDR S.aureus clinical isolates was detected.

\section{Conflicts of Interest: None.}

\section{References}

1. Schindler BD,Kaatz GW. Multidrug Efflux Pumps of Gram-Positive Bacteria. Drug Resist Updat.. 2016; 27:1-13.

2. Jang J. Multidrug efflux pumps in Staphylococcus aureus and their clinical implications. J. Micro. 2016; 54(1):1-8.

3. Schindler B D, Frempong-Manso E, DeMarco C E, Kosmidis C, Matta V, Seo S M, etal. Analyses of Multidrug Efflux Pump-Like Proteins Encoded on the Staphylococcus aureus Chromosome. Anti. Agents Chemo. 2015; 59(1):747-748.

4. Nakaminami $H$, Noguchi $N$ and Sasatsu $M$. Fluoroquinolone efflux by the plasmid-mediated multidrug efflux pump QacB variant QacBIII in
Staphylococcus aureus. Anti. Agents Chemo. 2010; 54:4107-4111.

5. Jaglic Z,Cervinkova D. Genetic basis of resistance to quaternary ammonium compounds, the qacgenes and their role: a review. Vet Med. 2012; 57(6): 275-281.

6. Wassenaar $\mathrm{T}$ M, Ussery $\mathrm{D}$ W,Ingmer I. The qac C Gene Has Recently Spread between Rolling Circle Plasmids of Staphylococcus, Indicative of a Novel Gene Transfer Mechanism. Front Micro.2016; 7:1528-1539.

7. Yan N. Structural advances for the major facilitator super family (MFS) transporters. Trends. Biochem . Sci .2013; 38(3):151-160.

8. Du D, Veen H W, Murkami S. Pos K M,Luisi B F. Structure, mechanism and cooperation of bacterial multidrug transporters. Curr. opin .Struct .Biol .2015; 33:76-91.

9. Costa S, Miguel V, Amaral L and Couto I. Multidrug Efflux Pumps in Staphylococcus aureus: Open. Micro. J. 2013; 7:59-71.

10. Johari S A, Motar M, SuhailiZ,Isa M M, Mustafa S, Ali A M . Efflux genes and active efflux activity detection in Malaysian clinical isolates of methicillinresistant Staphylococcus aureus (MRSA). J. Basic. Micro. 2008; 48:241-245.

11. Holler J G, Christensen B, Slotved H, Rasmussen B, Guzman A, Olsen C 1, et al. Novel inhibitory activity of the Staphylococcus aureusNorA efflux pump by a kaempferolrhamnoside isolated from PersealingueNees. J Anti Chemo.2012; 67:11381144.

12. Wassenaar T M, Ussery D W,Ingmer I. The qacC Gene Has Recently Spread between Rolling Circle Plasmids of Staphylococcus, Indicative of a 
Novel Gene Transfer Mechanism. Front Micro.2016; 7:1528.

13. William B W, Paul D V, George M G, Dorothy J, Noel R K, Wolfgang L, et al. Bargey's Manuel of systematic Bacteriology. $2^{\text {nd }}$ ed. Com. 2009 ; pp:392433.

14. Martins M, Viveiros M, Couto I, Costa SS,PachecoT,Fanning S, et al . Identification of efflux pump-mediated multidrug-

resistant bacteria by the ethidium bromide-agar cartwheel method. In Vivo.2011; 25(2):171-178.

15. Clinical and Laboratory standards institute (CLSI). Methods for Dilution Antimicrobial Susceptibility Tests for Bacteria That Grow Aerobically; Approved Standard-Ninth Edition.CLSI document M07-A9. Wayne, PA: CLSI .2015.35(2):1-50.

16. Kieser T. Preparation and analysis of genomic and plasmid DNA. Johnines Center, Norwich. NRU 7UTH, UK. 1995; PP:17.

17. Vali L, Davies S E, Lai L L, Dave J, Sebastian G B. Frequency of biocide resistance genes, antibiotic resistance and the effect of chlorhexidine exposure on clinical methicillin - resistant Staphylococcus aureus isolates. J. Anti Chemo.2008; 61:524-532.

18. Noguchi N, Suwa J, Narui K, Sasatsu M, Ito T, Hiramatsu K,et. al. Susceptibilities to antiseptic agents and distribution of antiseptic-resistance genes $q a c A / B$ and smrof methicillin-resistant Staphylococcus aureus isolated in Asia during 1998 and 1999. J Med Micro. 2005;54:557-565.

19. Al-Habdan W, Saad M, Kandala N .The Role and Effect of efflux pumps and efflux pumps inhibitor on methicillin resistant Staphylococcus aureus. G.J.B.B. 2017; 6(3):449-455.

20. Clinical and Laboratory standards institute (CLSI). Performance Standards for Antimicrobial Susceptibility Testing. 27th ed. Wayne, PA: CLSI. 2016.

21. Huet A L A, Raygada J L, Mendiratrtta K, Seo S M,Kaatz G W. .Multidrug efflux pump overexpression in Staphylococcus aureus after single and multiple in vitro exposures to biocides and dyes. Micro .2008; 154:3144-3153.

22. Zmantar T, Kouidhi B, Miladi H, Bakhrouf A. Detection of macrolide and disinfectant resistance genes in clinical Staphylococcus aureusand coagulase-negative staphylococci. BMC Micro .2011; 4:453.

23. Heir E, Sundheim G, Holck A L. Resistance to quaternary ammonium compounds in Staphylococcus spp. isolated from the food industry and nucleotide sequence of the resistance plasmid pST827. J . Appl Bact. 1995; 79:149-156.

24. Mayer S, Boos M, Beyer A, Fluit A D, Schmitz C. Distribution of the antiseptic resistance genes qacA, qacB and qacC in 497 methicillin-resistant and susceptible European isolates of Staphylococcus aureus. J. Anti Chemo.2001; 47:893-905.

25. Saber N,Kandala N. J. The inhibitory effect of fluphenazinedecanoate and caffeine on Staphylococcus aureus efflux pumps. Cur. Res. Micro. Biotech.2108; 6(2):1530-1535.

26. Redgrave L S, Sutton S B, Webber M A, Piddock L J. Fluoroquinolone resistance: mechanisms, impact on bacteria, and role in evolutionary success. Trends in Micro 2014; 22(8).

27. Otter J A, Patel A, Cliff P R,Halligan E P, Tosas O,Edegeworth J D. Selection for qacA carriage in CC22, but not CC30, methicillin-resistant Staphylococcus aureusbloodstream infection isolates during a successful institutional infection control programme. J Anti Chemo.2013; 68: 992-999.

28. Mohammed H A,Kandala N J . Use Multiplex PCR Technique for Distribution the Accessory Gene Regulatory Polymorphisms among Baghdad Clinical Staphylococcus aureus Isolates and its Correlation to Cassette Type. World. J. Exp . Biosci. 2017; 5(1):2329. 


\section{التحري عن المورث الجديدالمقاوم للمطهربين عزلات المكورات العنقودية الذهبية المتعددة المقاومة للمضادات الحيوية والمعزولة من مصادرسرين عزية المكورية مختلفة}

هبة عبد الامير محمد
نهى جوزيف قندلا

قسم التقنيات الاحيائية، كلية العلوم، جامعة بغداد، بغداد، العر اق.

الخلاصة:

يودي الاستخدام المتز ايد للمركب المطهر الى خلق ضخ انتقائي وظهورمقاومة للمطهرات بين المكورت العنقودية الذهبية،وا آلية

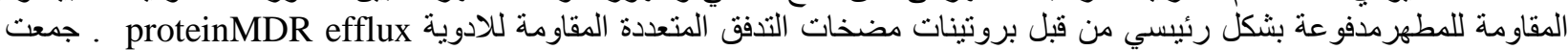

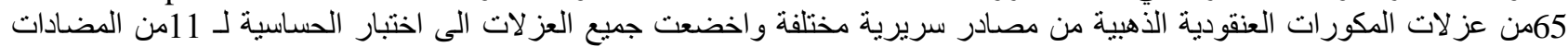

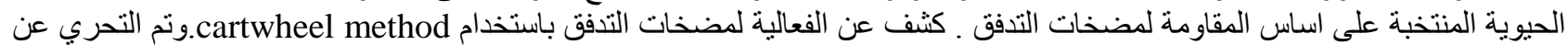

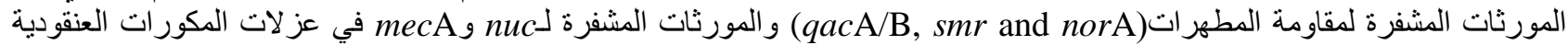

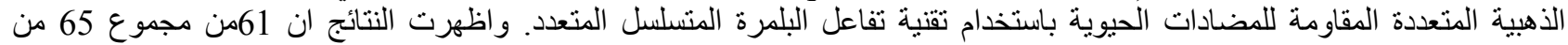

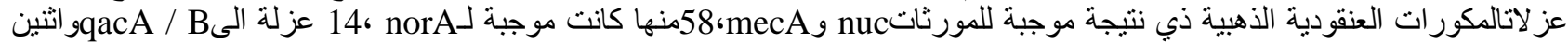

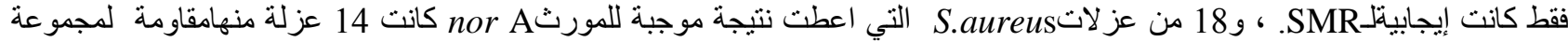

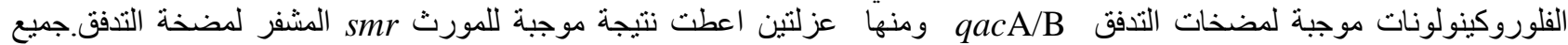

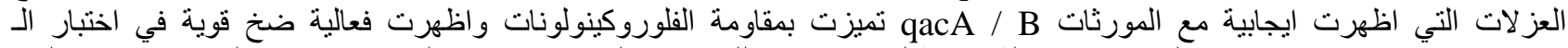

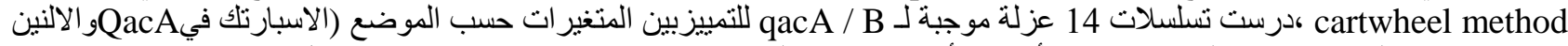
في QacB)، امتلكت ثلاث من العز لات حمض أميني الأسبار اجين في الموضع 323 واعتبر نوع جديد اكتشف لاول مرة. الكلمات المفتاحية: مضخات التدفق، تفاعل البلمرة المتسلسل المتعدد، الدكورات العنقودية الذهبية، محدد نو اقل الغثاء . 